\title{
Citrulline Measurement
}

National Cancer Institute

\section{Source}

National Cancer Institute. Citrulline Measurement. NCI Thesaurus. Code C122109.

The determination of the amount of citrulline present in a sample. 